\title{
Inter-comparison exercises on dissolved gases for groundwater dating - (1) Goals of the exercise and site choice, validation of the sampling strategy
}

Labasque T.*1, Aquilina L. ${ }^{1}$, Vergnaud V. ${ }^{1}$, Hochreutener R. ${ }^{1}$, Barbecot F. $^{2}$, Casile G. ${ }^{3}$

${ }^{1}$ Geosciences Rennes - OSUR, CNRS - Université de Rennes 1 - Campus Beaulieu - 263 av. du Gal Leclerc - 35042 Rennes cedex - France

${ }^{2}$ Université du Quebec à Montréal ; Case postale 8888, Succursale Centre-ville Montréal (Québec) H3C 3P8, CANADA

${ }^{3}$ CFC laboratory US Geological Survey 432 National Center 12201 Sunrise Valley Drive Reston, VA 20192, USA

*corresponding author :

Email : thierry.labasque@univ-rennes1.fr

Tel : 33223235749

\section{Abstract}

Two international inter-comparison exercises devoted to dissolved gases and isotope analyses in groundwater, used as tools for groundwater dating were organized in 2012 in France

(IDES- Université Paris Sud - CNRS and OSUR - Université Rennes 1- CNRS). The goal was to compare sampling and analytical protocols through results obtained by the community of groundwater dating laboratories. The two exercises were: GDAT1 on three supply boreholes in a homogeneous sand-aquifer of Fontainebleau (Paris Basin, France) and GDAT2 on two supply boreholes (shallow and deep) in a fractured rock aquifer in French Brittany. This twostep exercise is the first exercise which included a large number of gases and isotopes usually used in groundwater as dating tools and also permit to discuss the uncertainties related to sampling protocols issuing from each laboratory methods. The two tests allowed 31 Laboratories from 14 countries to compare their protocols for both sampling and analyses. This paper presents the participants and parameters measured, and focuses on the validation of the sampling strategy. Two laboratories analyzed $\mathrm{CFC}_{\text {and }} \mathrm{SF}_{6}$ samples collected at regular intervals during the sampling operations in order to verify water homogeneity. The results obtained by the two "reference" laboratories along with monitoring of field parameters 
showed no clear trend of gas concentration or physic-chemical properties. It can be concluded that the pumped groundwater composition remained constant during sampling. This study also shows the potential for relatively constant pumped groundwater composition from a specific well despite the complexity and/or mixing processes that may occur at a larger scale in the aquifer.

Keywords : inter-comparison exercise, groundwater dating, environmental tracers

\section{Introduction}

Groundwater dating through dissolved gases $\left(\mathrm{CFCs}_{\mathrm{SF}}\right)$ and isotopic analyses $\left({ }^{14} \mathrm{C},{ }^{3} \mathrm{H},{ }^{3} \mathrm{He}\right.$, ${ }^{20} \mathrm{Ne},{ }^{40} \mathrm{Ar},{ }^{84} \mathrm{Kr}$ ) has been used for decades, (Busenberg and Plummer, 1992, 2000; Clark and Fritz, 1997; Solomon et al., 1993). More recently ${ }^{39} \mathrm{Ar},{ }^{81} \mathrm{Kr},{ }^{85} \mathrm{Kr}$ methods (Loosli et al., 1999), $\mathrm{SF}_{5} \mathrm{CF}_{3}$ and CF-13 (Busenberg and Plummer, 2008) appeared to have great potential. Environmental tracers such as dissolved gases and various isotopes of some gases are mostly present in very low concentrations in groundwater, due to their low concentration in the atmosphere and their low solubility in water. $\mathrm{CFCs}$ and $\mathrm{SF}_{6}$, among the most used dissolved gases, have ground water concentrations of about $10^{-12}$ to $10^{-16} \mathrm{~mol} / \mathrm{kg}$, respectively. Noble gas isotopes such as ${ }^{3} \mathrm{He},{ }^{4} \mathrm{He},{ }^{20} \mathrm{Ne},{ }^{22} \mathrm{Ne},{ }^{36} \mathrm{Ar},{ }^{40} \mathrm{Ar},{ }^{84} \mathrm{Kr}$ and ${ }^{132} \mathrm{Xe}$ have ground water concentrations between $10^{-4}$ to $10^{-15} \mathrm{CCstp} / \mathrm{g}$. These concentrations require very precise sampling protocols, storage conditions and very sensitive analytical methods. Degassing and air contamination must be avoided at each step of sampling and analysis. Detailed sampling protocols have been published. (IAEA, 2006; Busenberg and Plummer, 1992, 2000).

However, each laboratory uses its own specific and adapted sampling and analytical protocol for historical reasons, or due to specific improvements. For example, in the case of CFC sampling, glass bottles with various caps and volumes, as well as steel flasks or field gas extraction can be used. Both headspace and purge-and-trap extraction are used for $\mathrm{SF}_{6}$ analysis each requiring different sampling procedures. These differences in protocols may introduce a high degree of variability among different laboratories' measurements. 
More than 40 laboratories worldwide use these environmental tracers for hydrogeological characterization. Guidebooks devoted to these methods have been published by the International Atomic Energy Agency (IAEA, 2006, 2011) and this topic has been the subject of special journal issues (Osenbrück et al., 2010). Analytic intercomparison has been carried out for ${ }^{3} \mathrm{H},{ }^{14} \mathrm{C}$ and stable isotopes (IAEA organization). However an inter-comparison exercise devoted to groundwater dating has never been carried out. The aim of the 2012 GDAT inter-comparison exercise was to compare how the various sampling and analytical protocols used by different laboratories could affect (or not) the concentration determination of environmental tracers and groundwater dating.

A source of standardized water to sample for each laboratory participating in the intercomparison was established. Laboratory methods such as an equilibrated water tank were difficult to run at the scale of 30 laboratories requiring hundreds of samples. It was decided to run the exercise under field conditions by sampling ground water at a variety of boreholes. Sampling of groundwater from boreholes for drinking-water supply offers several advantages. It ensures a good renewal of water, stabilized water level in the borehole and stable chemistry and temperature. Knowledge of dissolved gas concentrations in chosen boreholes had to be established before the exercise through previous studies, in order to better design the exercise and focus on specific concentration ranges of the target analytes. The desired target ground waters were (1) modern waters (age less than $15 \mathrm{yrs}$ ) where ${ }^{3} \mathrm{H}$ and $\mathrm{CFC}$ groundwater dating methods have a poor precision but $\mathrm{SF}_{6}$ has high resolution, and (2) «blank" samples (age greater than $60 \mathrm{yrs)} \mathrm{to} \mathrm{test} \mathrm{for} \mathrm{sampling} \mathrm{contamination.} \mathrm{A} \mathrm{key} \mathrm{concern}$ in the design of such an intercomparison was to make sure that all participants sampled a similar groundwater. Although it appears as a trivial condition, constant field conditions and steady state chemistry for several hours of pumping can not be assumed. Besides being the necessary condition for the GDAT exercise, this point represents a fundamental question in chemical hydrogeology. Aquifers present a degree of heterogeneity which makes it difficult to interpret a unique sample as a part of complex mixing processes at various scales. The GDAT exercises thus raised a preliminary question of how to obtain a unique but steady state sample for 30 laboratories representing the same water chemistry.

The results of the intercomparison exercises are described in two companion papers, one devoted to CFCs and $\mathrm{SF}_{6}$ (Labasque et al. this issue), the second one to noble gases and ${ }^{3} \mathrm{H}$ (Visser et al., this issue). This paper presents the points that were discussed in order to define the strategy of the intercomparison exercises, the rules used to determine the sampling sites 
and the sampling strategy. We also present the geological and hydrogeological context of the sampling sites, the team who participated and the methods used.

\section{Materials and methods}

\section{Description of the sampling sites}

The inter-comparison exercise proposed in parallel to the GDAT-2012 meeting included two sampling phases in homogeneous and heterogeneous fractured rock aquifers (GDAT1 and GDAT2) which are described below

Homogeneous aquifer: The first GDAT1 exercise was carried out in January 2012 close to the Fontainebleau forest (about $40 \mathrm{~km}$ south of Paris) in sandy homogeneous aquifers in the Paris basin. The Fontainebleau site is devoted to drinking water abstraction and includes two aquifers, the Albian sand aquifer and the Fontainebleau Oligocene sand aquifer.

This basin is a multi-layered aquifer-aquitard system associated with a southeast to northwest topographically-driven flow with recharge zones at the highest outcrops and discharge zones along the main rivers (Seine, Somme) or in the Manche Channel. Some of these aquifers are exploited, e.g. the Albian sand formation, a deep protected aquifer, is used for water supply. The Albian sands of the Paris Basin represent one of the shallowest (600 mbgl below ground level) confined aquifers in this thick sedimentary basin. Hydrogeological informations lead us to identify and select a flow line between the recharge area (Gien-Auxerre, SE) and the middle of the Basin (Paris). This flow line is characterized by a large cone of depression beneath Paris induced by the massive pumping performed since last century. A recent hydrological and geochemical study (Raoult et al., 1997) demonstrates that locally the Albian groundwater is variously mixed with water rising up from the underlying Neocomian aquifer.

One of the three boreholes chosen during the Gdat1 exercise is screened at 556 to $592 \mathrm{mbgl}$ in the Albian aquifer. This borehole was under continuous pumping until a month before GADT1 sampling.

The Fontainebleau Oligocene sand-aquifer was chosen because it is hydrogeologically well known from previous tracer investigations (Schneider, 2005; Corcho et al., 2007, 2009). It is located in the shallower part of the Paris Basin and constituted of very fine well-sorted silica grains. The Fontainebleau sand-formation has a thickness of 50-70 m, a hydraulic 
transmissivity of $1 \times 10^{-3}$ to $5 \times 10^{-3} \mathrm{~m}^{2} \cdot \mathrm{s}^{-1}$ and a mean total porosity of about $25 \%$ (Mégnien, 1979; Mercier, 1981; Ménillet, 1988). The hydrogeological situation is characterized by spatially extended recharge rates ranging from 100 to $150 \mathrm{~mm} / \mathrm{yr}$ (Corcho et al., 2007). Wells in the Fontainebleau sand-aquifer have generally long screened intervals. The boreholes SLP4 and SLP5 were selected for the study for two main reasons : i) because the use of these wells for water supply is continuous and the drawdown was stabilized weeks before sampling, and ii) because the age structure of groundwater is relatively well constrained. Corcho et al. (2007) concluded that flow paths intercepted by the well have residence-times that range from modern to a few hundreds years, with a mean exponential residence-time of about 100 years. The SLP4 and SLP5 wells have a long screened interval between 40 to $54 \mathrm{mbgl}$ (meter below ground level) and 45 to $68 \mathrm{mbgl}$ respectively, entirely within the sand formation, with an inner diameter of $0.6 \mathrm{~m}$ of CUAU inox filter.

Sampling operations were carried out on $1^{\text {st }}$ and $2^{\text {nd }}$ of February 2012 at an unusual outdoor temperature about $-4^{\circ} \mathrm{C}$. Teams present on site met the day before in order to organize the sampling operations. The three water supply boreholes were sampled successively, directly at the pump tap which provided stabilized water. Except for the borehole in the Albian formation, where the team had to leave before the end of sampling due to an unexpected decision of the site management, sampling took place without technical problems.

Heterogeneous aquifer: The second inter-comparison exercise, GDAT2 was carried out on 18 and 19 of October 2012 in a fractured rock aquifer North of Rennes (France). This water plant is located in Brioverian schists made of alternating centimeter-thick layers of sandstones, silts and clay-rich layers (Trautmann et al, 2000). Alteration of this crystalline rock leads to the formation of an unconsolidated saprolite observed during drilling along the first 10 to $15 \mathrm{~m}$. The site includes two supply wells : a shallow one $15 \mathrm{~m}$ depth, named "Captage", and a deep one $105 \mathrm{~m}$-depth, named "forage". Pumping for water supply is around $10 \mathrm{~m}^{3} / \mathrm{h}$. Previous studies (Ayraud et al., 2006) indicated that the shallow well provides "young" water from the shallow weathered compartment with residence time ranging from 15 to 25 yrs. The deep well, in the fractured fresh rock, provides "old" waters from fault zones below $40 \mathrm{~m}$ depth. Groundwater at this depth presents higher salinity (mean $\mathrm{Cl}^{-}=100 \mathrm{mg} / \mathrm{L}$ ) indicating a complex origin and mixing between the shallow compartment and deep groundwater. This well has been monitored since the beginning of pumping in 2003. Although a drift of the composition has been observed during this period, the evolution is very slow and offers some guaranty of stability for a short pumping exercise. Although (usual) slightly rainy weather 
made conditions more difficult, sampling took place without any technical problems and all sampling planned was realized, as well as the test of a passive-sampler chain in a monitoring piezometer.

\section{Sampling conditions}

For the two sites, each borehole was equipped with nylon tubing lines. Each line was kept to minimum practical length. One line was dedicated to $\mathrm{CFCs}_{\text {and }} \mathrm{SF}_{6}$ sampling, the second one to noble gases and tritium, and the last one to specific sampling (field extraction or large volume sampling). The flow of each line was around $300 \mathrm{l} / \mathrm{h}$. After one hour of flushing, the field parameters were stabilized and sampling started with an order decided by the organizers and all the participants. A critical point was the organization of the sampling steps due to the numerous persons waiting for sampling in a very small and confined place. Each Lab's sampling containers were labeled and the order and the time of sampling of each Lab's containers were thus written down along with field parameters during each sampling step.

\section{Insurance of sample water homogeneity}

As mentioned in the introduction, insurance of the homogeneity of all samples collected during the experiment was a necessary condition. In order to measure water homogeneity, three different parameters were monitored during sampling : (1) groundwater samples for $\mathrm{CFC}$ and $\mathrm{SF}_{6}$ analyses were collected at the beginning, in the middle and at the end of sampling operations. These samples were analyzed by two different laboratories (Géosciences Rennes (GR) and USGS Reston laboratory). (2) Major anions and dissolved gases $\left(\mathrm{N}_{2}\right.$ and Ar) were also sampled and analyzed in the same way in the Geosciences Rennes Laboratory.

3) Field parameters ( $\mathrm{T}^{\circ}$, Cond, $\mathrm{pH}, \mathrm{Eh}$, and dissolved oxygen, WTW sensors) were monitored during the entire sampling operation in order to detect any obvious change in the water chemical composition.

$\mathrm{CFC}$ and $\mathrm{SF}_{6}$ were sampled in steel ampouls (40ml and $300 \mathrm{ml}$ respectively) by GR and analysed by Purge and trap and GC/ECD. USGS samples were collected in glass bottles (150 $\mathrm{ml}$ for $\mathrm{CFC}$ and $1 \mathrm{~L}$ for $\mathrm{SF}_{6}$ ). Analytical systems used at the USGS lab are described in Busenberg and Plummer (1992, 2000). Uncertainty was fixed at 3\% for values above $0.1 \mathrm{pmol} / \mathrm{kg}$ for $\mathrm{CFC}$ and $0.1 \mathrm{fmol} / \mathrm{kg}$ for $\mathrm{SF}_{6}$. For lower values, uncertainty was fixed at $20 \%$. Those values are generally used by most authors (Busenberg and Plummer, 1992, 2000; Volmer and Weiss, 2002). For anions analyses, ion chromatography (DIONEX DX120) was used with an uncertainty of about $5 \%$. For $\mathrm{Ar}$ and $\mathrm{N}_{2}$ gas, chromatography was used with a 
thermal conductivity detector $(\mu \mathrm{GC} / \mathrm{TCD})$ after headspace extraction following the Sugisaki et al. method (Sugisaki et al, 1987) with analytical precision of 5\%. The variations are expressed as the difference between the value at the end and the value at the beginning of the pumping step, divided by the analytical uncertainty (tables 2 and 3 ).

\section{Results of the field GDAT1 and GDAT2 exercises}

The list of participants is presented in table 1 . Thirty one laboratories from 14 countries participated in the intercomparison exercises. Parameters measured by each team and their contributions to each exercise are indicated. Details on the sampling system are also specified. The participation in an exercise dedicated to $\mathrm{CFC}$ and $\mathrm{SF}_{6}$ gas standard analysis is also indicated. Results of the exercises are discussed in specific companion publications.

Data analysis focused on (1) field parameters, anions, $\mathrm{N}_{2}$, Ar (Table 2), (2) CFCs and $\mathrm{SF}_{6}$ measurements (Table 3) realized on SLP4 (GDAT1), Captage and Forage boreholes (GDAT2) at the beginning and end of sampling and on 3) continuous field parameters acquisition. For SLP5 and Albian wells, the time was too short to sample gases and anions at the end of sampling operations. However, no modification of the field parameters occurred during sampling of these boreholes.

$\mathrm{CFC}$ and $\mathrm{SF}_{6}$ concentration evolutions during sampling operations are illustrated in fig 1, 2 and 3 for SLP4, Captage and Forage boreholes respectively. For the GR and USGS laboratories, A and E labels are used.

SLP4 sampling was realized by all the participants within 4 hours. Conductivity, $\mathrm{pH}$, Redox and major anion concentrations remained unchanged during the sampling period (Table2). A temperature rise was noticed $\left(+3.3{ }^{\circ} \mathrm{C}\right)$. A slight decrease (Table 3$)$ in the $\mathrm{CFC}-113$ value $(-2$ and -1 for GR and USGS, respectively) and a decrease in the USGS values for CFC-11 and CFC-12 (-5) can be seen. The depletions of CFC-11 and CFC-12 were not measured by GR. The CFC-12 measured by USGS at $\mathrm{t}+4 \mathrm{~h}$, is in agreement with values obtained by GR. So a bad sampling at the beginning of the pumping could explain the possible contamination of the USGS sample. For CFC-11, the initial value (t0) measured by USGS is in agreement with GR values, no reasons was found to explain the decrease measured by USGS, except a slight degradation of this compounds before the analyze for USGS samples. CFC-113 
concentrations measured are low (0.04 to $0.07 \mathrm{pmol} / \mathrm{kg})$ and close to quantification limits, around $0.024 \mathrm{pmol} / \mathrm{kg}$ (Volmer and Weiss, 2002). The modifications of the CFC-113 concentrations during sampling and observed by the two laboratories could be due to rinsing of the tubes. Nylon tubing is not ideal for CFC sampling closed to detection limit, copper tubing should be preferred (Busenberg and Plummer, 1992). $\mathrm{SF}_{6}$ measurements show almost unchanged concentrations for GR and USGS (-2 and 0 respectively). As a whole, it can be concluded that no major modification of the gas water composition was noticed during sampling of SLP4. Very low CFCs and $\mathrm{SF}_{6}$ concentrations were not affected by the $4 \mathrm{hrs}$ long sampling period.

Groundwater sampling in the Captage borehole was completed within 6 hours. A large change in the redox potential $(+7)$ and a slight decrease in major anion concentrations were noticed $\left(\mathrm{Cl}^{-}:-5 ; \mathrm{NO}_{3}{ }^{-}:-10 ; \mathrm{SO}_{4}{ }^{2-}:-1\right)$. Conductivity, $\mathrm{pH}$, temperature, $\mathrm{N}_{2}$ and Ar concentrations remained unchanged during sampling. GR measured a decrease in CFC-113 (-10), not correlated with the other CFC or to USGS CFC-113 measurements. An increase of $\mathrm{SF}_{6}$ concentrations (+7) was measured by USGS but not by GR (-2). CFC-11 concentrations remained unchanged for the two laboratories. A decrease of CFC-12 concentrations was noticed by GR (-3) but not by USGS. Even if CFC and $\mathrm{SF}_{6}$ concentrations are high on Captage well, as compared to SLP4, differences between the beginning and the end of pumping are in the same range, without a clear trend.

Sampling by all the participants of the "Forage" borehole was completed within 6 hours. An increase in redox potential was measured $(+5)$, correlated to a decrease in nitrogen concentrations (-12). Other field parameters and Ar concentrations remained unchanged during sampling. An increase in CFC-11 concentration was measured by GR (+2) and USGS (+4). An increase in CFC-12 concentration was measured as well by GR (+4) but not by USGS (-1). GR measured a slight increase in CFC-113 (+2) while a slight modification of CFC-113 concentration was measured during the last 3 hours of pumping ( 0.011 to $0.025 \mathrm{pmol} / \mathrm{kg}$ ) by USGS. As for the SLP4 borehole, CFC-113 concentrations were close to the detection limits $(0.01 \mathrm{pmol} / \mathrm{kg}$ and $0.024 \mathrm{pmol} / \mathrm{kg})$ and these evolutions are probably not significant. This is confirmed by the constant $\mathrm{SF}_{6}$ concentrations measured by the two laboratories (+1 for GR and -1 for USGS).

\section{Discussion and conclusion}


These GDAT exercises consisted of the sampling of various boreholes in two sand-aquifers and the two compartments of a heterogeneous fractured rock aquifer. Previous studies have shown that these wells belong to a complex hydrogeological structure where large mixing processes occur. The Albian well intercepts a $100 \mathrm{~km}$ scale flow line (Corcho-Alvarado et al., 2007) whilst the two wells of the fractured rock site belong to a large mixing process between surface waters from the shallow weathered compartment, and deep and moderately saline waters (Ayraud et al., 2008). The task of sampling groundwater with a relatively constant composition through time is thus not trivial. Furthermore, the intercomparison exercise required a very high level of homogeneity for chemical concentrations at the picomole or femtomole scale. The sampling procedure of the GDAT sampling operations thus included the collection of replicate reference samples during the sampling. These samples were analyzed by two laboratories in order to provide validity to the experiment.

All the measurements out of the reference samples collected during the GDATexercises showed no clear and significant modification of the composition of the water pumped during the sampling periods. Even if some samples of $\mathrm{CFC}$ and $\mathrm{SF}_{6}$ can showed slight differences between the two laboratories, and a slight decrease or increase during pumping, no clear trend was noticed at the picomole level for $\mathrm{CFC}$ and fentomole level for $\mathrm{SF}_{6}$ by the two reference labs. This point confirms that the necessary condition of a homogeneous groundwater body sampled by all the GDAT participants has been fulfilled. It also shows that the great complexity of an aquifer does not prevent it from producing a relatively constant groundwater flow from a specific well. Comparison of the results of this study with previous studies shows that this is true at the scale of several years and the result of this study shows that this is also true at a very high degree of precision for at least several hours of sampling.

Although this point was discussed and remained a challenge at the beginning of the GDAT experiment design, this study shows that it is possible to get a homogeneous sample for many participants to share from field boreholes. It should be noted that the choice of supply boreholes it undoubtedly an important condition for success. These wells have relatively high permeability and steady state hydrogeological conditions which make the constancy of water composition more likely. The pumping equipment and all associated piping and tubing are permanently installed and most likely in equilibrium with the pumped water mixture.

Furthermore sampling directly at the well tap provided similar pumping conditions for all participants during the sampling period. 
This long-term sampling with various methods also provided several lessons regarding sampling. Most of the discrepancy of the results between laboratories could be due to bad sampling with for example bubble entrapment or air contact. Sample tubing has to be rinsed for hours before final sample collection. Copper tubes should be preferred for low concentrations CFC, in order to prevent contamination. Finally, an order of sampling has to be followed and "reference" samples have to be inserted regularly in order to verify the stability of the water composition. Storage time should also be taken into account for results interpretation, due to risk of contamination or degradation of dissolved gases.

Acknowledgments : Authors would like to thank the council of Betton town and the water structure SMPBR, VEOLIA EAU and Source du Val Saint Lambert Company, for site acess and facilities for groundwater sampling. The GDAT intercomparison exercise benefitted from the help and/or funding of the International Atomic Energy association, IDES laboratory (UMR 8148), Université Rennes1, CNRS, OSUR (Rennes Universe Sciences Observatory), Géosciences Rennes laboratory, French Ministry for Education and Research, Région Bretagne and VEOLIA Eau. Financial and scientific support was also provided by the H+ network (Hydrogeology site network, INSU-CNRS).

\section{References}

Ayraud, V., Aquilina, L., Pauwels, H., Labasque, T., Pierson-Wickmann, A.-C., Aquilina, A.M. and Gallat, G., 2006. Physical, biogeochemical and isotopic processes related to heterogeneity of a shallow crystalline rock aquifer. Biogeochemistry 81(3):331-347.

Ayraud V., Aquilina L., Labasque T., Pierson-Wickmann A.C., Molenat J., Pauwels H., Fourre E., Tarits C. Bour O., Durand V., Le Corre P ; Merot P., Davy P., 2008. Compartmentalization of physical and chemical properties in hard-rock aquifers deduced from chemical and groundwater age analyses. Appl. Geochem, 23(9): 2686-2707

Busenberg, E., and Plummer, L.N., 1992. Use of chlorofluorocarbons (CCl3F and CCl2F2) as hydrologic tracers and age-dating tools: Example - The alluvium and terrace system of central Oklahoma. Water Resources Research, 28(9), 2257-2284. 
Busenberg E., Plummer N., 2000. Dating young groundwater with sulfur hexafluoride: Natural and anthropogenic sources of sulfur hexafluoride Water Res., 36, 3011-3030,

Busenberg E., Plummer L. N., 2008. Dating groundwater with trifluoromethyl sulfurpentafluoride (SF5CF3), sulfur hexafluoride (SF6), $\mathrm{CF} 3 \mathrm{Cl}$ (CFC-13) and $\mathrm{CF} 2 \mathrm{Cl} 2$ (CFC-12). Water Resour Res 44/W2431.

Clark ID, Fritz P., 1997. Environmental Isotopes in Hydrology. Boca Raton, FL: Lewis. 328pp.

Corcho Alvarado, J. A., et al., 2007. Constraining the age distribution of highly mixed groundwater using 39Ar: A multiple environmental tracer $\left({ }^{3} \mathrm{H} /{ }^{3} \mathrm{He},{ }^{85} \mathrm{Kr},{ }^{39} \mathrm{Ar}\right.$, and $\left.{ }^{14} \mathrm{C}\right)$ study in the semiconfined Fontainebleau Sands Aquifer (France), Water Resour. Res., 43, W03427.

Corcho Alvarado J. A., F. Barbecot, R. Purtschert, M. Gillon,W. Aeschbach-Hertig, and R. Kipfer, 2009. European climate variations over the past half-millennium reconstructed from groundwater. Geophys Res Let., 36, L15703.

IAEA (International Atomic Energy Agency), 2006. Use of chlorofluorocarbons in hydrology: a guidebook. IAEA, Vienna.

IAEA (International Atomic Energy Agency), 2011. Dating old groundwater: a guidebook. IAEA, Vienna

Loosli, H. H., B. E. Lehmann, and W. M. Smethie, 1999. Noble gas radioisotopes: ${ }^{37} \mathrm{Ar},{ }^{85} \mathrm{Kr}$, ${ }^{39} \mathrm{Ar},{ }^{81} \mathrm{Kr}$, in Environmental Tracers in SubsurfaceHydrology, edited by P. G. Cook, and A. L. Herczeg, pp. 379-396, Springer, New York.

Mégnien, C. 1979. Hydrogéologie du centre du bassin de Paris. Mémoire BRG98, BRGM, Orléans, France, 522p.

Ménillet F. 1988. Meulières, argiles à meulières et meuliérisation: historique, évolution des termes et hypothèses génétiques [Meulières, Clay meulières and meuliérisation: historical evolution of the terms and assumptions genetic]. Bull Inf Géol Bassin Paris 25(4):71 - 79

Mercier R., 1981. Inventaire des ressources aquifères et vulnérabilité du département des Yvelines. Rapport BRGM., 81SGN3481DF, Service géologique régional Ile de France. 
Osenbrück K., Weise S.M., Newman B.D., 2010. Selected papers from the international workshop G-DAT 2008: groundwater dating using environmental tracers. Isot Environ Health Stud 46/257-258.

Raoult, Y., Boulègue, J., Lauverjat, J. and Olive, P., 1997. C. R. Acad. Sci. Paris, 325, 419-25.

Phillips F.M. and Castro M.C., 2003. Groundwater dating and residence-time measurements, pp. 451-497. In Surface and Ground Water, Weathering, and Soils (ed. J.I.Drever) Vol.5 Treatise on Geochemistry (eds. H.D.Holland and K.K.Turekian), Elsevier, Oxford.

Schneider V., Barbecot F., Bergonzini L., Marlin C., Massault M., and Dever L., 2005. Accroissement récent des teneurs en sulfates dans la nappe des sables de Fontainebleau : origines et implications pour la gestion de cette ressource. Bull. Assoc. Géol. Bassin Paris, 42, 91-94.

Solomon, D.K., Schiff, S.L., Poreda, R.J. and Clarke, W.B., 1993. A Validation of the ${ }^{3} \mathrm{H} /{ }^{3} \mathrm{He}$ Method for Determining Groundwater Recharge. Water Resources Research, 29(9): 2951-2962.

Sugisaki R., K Taki, 1987. Simplified analyses of He, Ne, and Ar dissolved in natural waters. Geochem. J., 21, 21-23.

Trautmann F, Paris F \& Carn A., 2000. Carte géologique de la France au 1/50000. Feuille de Rennes n³17. BRGM, Orléans.

Vollmer M. K., Weiss R. F., 2002. Smultaneous determination of sulfur hexafluoride and three chlorofluorocabons in water and air. Mar. Chem. 78, 137-148.

Figure Captions 


\begin{tabular}{|c|c|c|c|c|c|c|}
\hline Name & team & parameters & $\begin{array}{l}\text { Sampling } \\
\text { system }\end{array}$ & Gdat1 & Gdat2 & Air std \\
\hline $\begin{array}{ll}\text { Goody } & \text { D, } \\
\text { Darling G. } & \end{array}$ & BGS, England & CFCs, $\mathrm{SF}_{6}$ & Glass bottles & $x$ & $x$ & $x$ \\
\hline \multirow[t]{2}{*}{$\begin{array}{ll}\text { Sukow A., } & \text { A. } \\
\text { Leaney F. } & \\
\end{array}$} & CSIRO, Autralia & CFCs, $\mathrm{SF}_{6}$ & Cap bottles & $x$ & $\mathrm{x}$ & $\mathrm{x}$ \\
\hline & & $\begin{array}{l}\text { Noble } \\
\text { gases, } \mathrm{He}\end{array}$ & Copper tubes & $x$ & $x$ & \\
\hline Oster H. & $\begin{array}{l}\text { Surenstofflabor, } \\
\text { Germany }\end{array}$ & $\mathrm{CFCs}, \mathrm{SF}_{6}$ & Cap bottles & $x$ & $x$ & \\
\hline \multirow[t]{3}{*}{$\begin{array}{l}\text { Matsumoto } \\
\text { T., Han L. }\end{array}$} & IAEA, Austria & CFCs & $\begin{array}{l}\text { Brown glass } \\
\text { bottles }\end{array}$ & $x$ & $x$ & \\
\hline & & Noble gases & Copper tubes & $\mathrm{X}$ & $x$ & \\
\hline & & Tritium & Glass bottles & $x$ & $x$ & \\
\hline \multirow[t]{5}{*}{\begin{tabular}{ll}
\multicolumn{2}{l}{ Aeschbach- } \\
Hertig W., \\
Freundt F., \\
Schneider \\
Reichel \\
Kaudse T.
\end{tabular}} & $\begin{array}{l}\text { IEP, Heidelberg, } \\
\text { Germany }\end{array}$ & CFCs, $\mathrm{SF}_{6}$ & $\begin{array}{l}\text { Steel } \\
\text { cylinder/Wash }\end{array}$ & $x$ & $x$ & $\mathrm{x}$ \\
\hline & & $\begin{array}{l}\text { He, noble } \\
\text { gases }\end{array}$ & bottles & $x$ & $\mathrm{x}$ & \\
\hline & & Tritium & Copper tubes & $x$ & $x$ & \\
\hline & & ${ }^{39} \mathrm{Ar}$ & Glass bottles & $x$ & $x$ & \\
\hline & & & Steel cyclinder & & & \\
\hline \multirow[t]{2}{*}{ Yoon Y. } & KIGAM, Korea & CFCs & Cap bottles & $\mathrm{x}$ & $\mathrm{x}$ & \\
\hline & & Tritium & Plastic bottles & & & \\
\hline $\begin{array}{l}\text { Busenberg E., } \\
\text { Casile J. }\end{array}$ & USGS, USA & CFCs, $\mathrm{SF}_{6}$ & Cap bottles & $x$ & $x$ & $x$ \\
\hline \multirow[t]{2}{*}{$\begin{array}{l}\text { Sliwka I., } \\
\text { Bielewski J. }\end{array}$} & INP, Poland & CFCs, $\mathrm{SF}_{6}$ & Steel cylinder & $x$ & $x$ & $x$ \\
\hline & $4 \sqrt{2}$ & Noble gases & Copper tubes & & & \\
\hline \multirow[t]{3}{*}{$\begin{array}{ll}\text { Solomon } & \text { K., } \\
\text { Rigby A. }\end{array}$} & $\begin{array}{l}\text { Utah university, } \\
\text { USA }\end{array}$ & CFCs, $\mathrm{SF}_{6}$ & Cap bottles & $x$ & & \\
\hline & $\mathrm{s}$ & Noble gases & Copper tubes & $\mathrm{X}$ & & \\
\hline & & tritium & Glass bottle & $x$ & & \\
\hline \multirow[t]{4}{*}{$\begin{array}{l}\text { Barbecot F., } \\
\text { Lefebvre K. }\end{array}$} & IDES, France & CFCs, $\mathrm{SF}_{6}$ & $\begin{array}{l}\text { Steels } \\
\text { ampouls }\end{array}$ & $x$ & & \\
\hline & & Tritium & Glass bottle & $\mathrm{X}$ & & \\
\hline & & ${ }^{14} \mathrm{C}$ & Plastic bottle & $x$ & & \\
\hline & & ${ }^{222} \mathrm{Rn}$ & Glass bottle & $x$ & & \\
\hline \multirow[t]{2}{*}{$\begin{array}{l}\text { Labasque T., } \\
\text { Aquilina L., } \\
\text { Vergnaud V., } \\
\text { Hochreutener } \\
\text { R. }\end{array}$} & $\begin{array}{l}\text { Géosciences } \\
\text { Rennes, France }\end{array}$ & $\mathrm{CFCs}, \mathrm{SF}_{6}$ & Steel ampouls & $x$ & $x$ & $x$ \\
\hline & & $\begin{array}{l}\text { Dissolved } \\
\text { gases (Ne, } \\
\begin{array}{ll}\mathrm{Ar}, \mathrm{O}_{2}, \mathrm{~N}_{2}\end{array}\end{array}$ & Glass bottles & $x$ & $x$ & $x$ \\
\hline
\end{tabular}




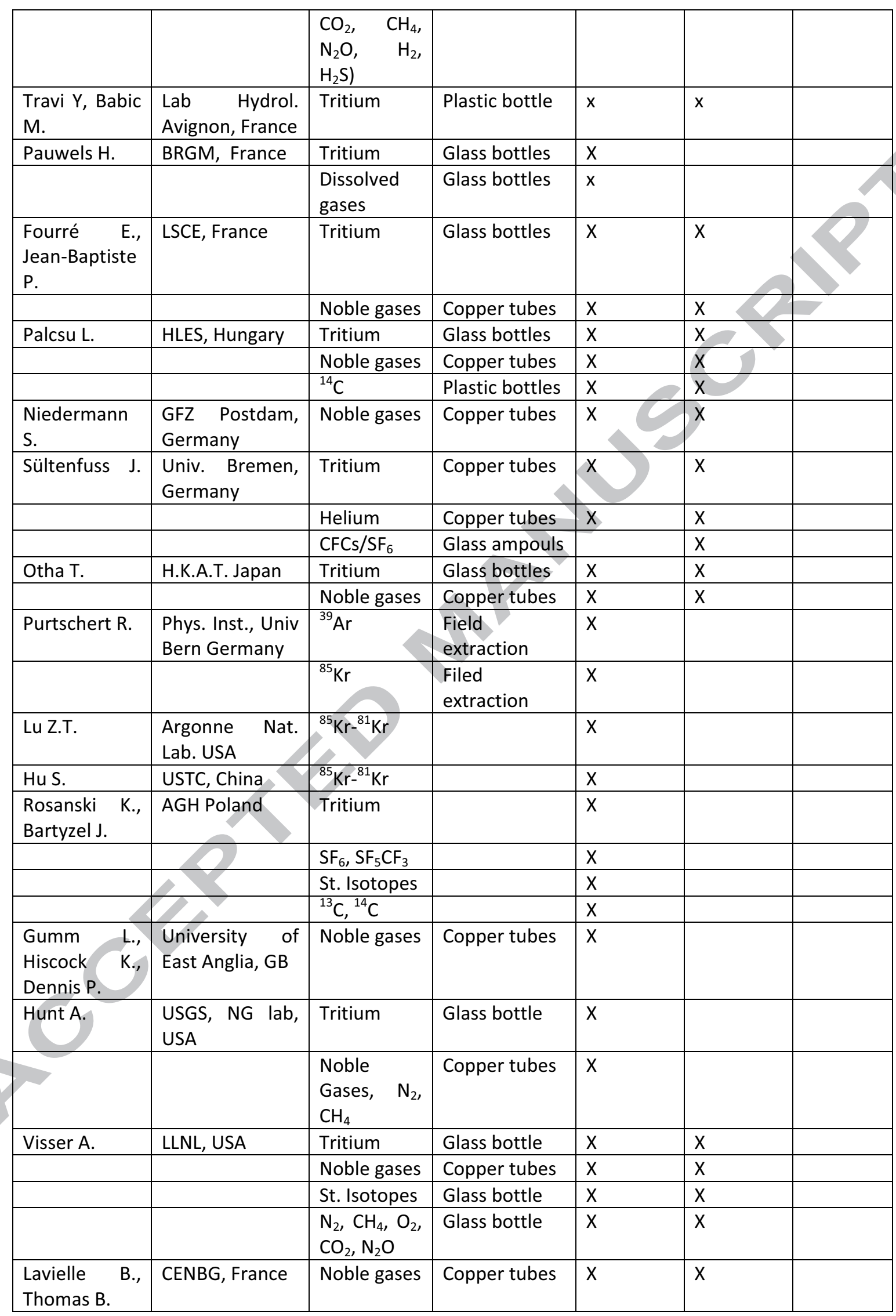




\section{ACCEPTED MANUSCRIPT}

\begin{tabular}{|l|l|l|l|l|l|l|}
\hline & & ${ }^{85} \mathrm{Kr},{ }^{81} \mathrm{Kr}$ & Glass bottle & $\mathrm{X}$ & $\mathrm{X}$ & \\
\hline Malov A. & $\begin{array}{l}\text { Russian } \\
\text { Academic of } \\
\text { Science, Russia }\end{array}$ & ${ }^{234} \mathrm{U},{ }^{238} \mathrm{U}$ & Plastic bottle & $\mathrm{X}$ & & \\
\hline $\begin{array}{l}\text { Le Gall La } \\
\text { Salle C. }\end{array}$ & LGIE, France & ${ }^{36} \mathrm{Cl}$ & Plastic bottle & $\mathrm{X}$ & $\mathrm{X}$ & \\
\hline $\begin{array}{l}\text { Brenwald M., } \\
\text { Kipfer R. }\end{array}$ & $\begin{array}{l}\text { EAWAG, } \\
\text { Switzerland }\end{array}$ & CFCs, SF6 & Steel ampouls & $\mathrm{X}$ & & \\
\hline & & Noble gases & Steel ampouls & $\mathrm{X}$ & & \\
\hline & & N2, O2 & Steel ampouls & $\mathrm{X}$ & & \\
\hline
\end{tabular}

Table 1: list of participants to the Gdat2012 inter-comparison exercise, parameters measured, sampling system and participation in a specific CFC, SF6 comparison exercise.

\begin{tabular}{|c|c|c|c|c|c|c|c|c|c|c|}
\hline Wells & $\begin{array}{l}\text { Samplin } \\
\text { g time }\end{array}$ & $\begin{array}{l}\text { Cond. } \\
(\mu \mathrm{S} / \mathrm{cm} \\
)\end{array}$ & $\mathrm{pH}$ & $\begin{array}{l}\mathrm{T} \\
\left({ }^{\circ} \mathrm{C}\right)\end{array}$ & $\begin{array}{l}\text { Redo } \\
\mathrm{x} \\
(\mathrm{mv})\end{array}$ & $\begin{array}{l}\mathrm{NO}_{3}(\mathrm{mg} / \mathrm{L} \\
)\end{array}$ & $\begin{array}{l}\mathrm{Cl}^{-} \\
(\mathrm{mg} / \mathrm{L} \\
)\end{array}$ & $\begin{array}{l}\mathrm{SO}_{4}^{2-} \\
(\mathrm{mg} / \mathrm{L} \\
)\end{array}$ & $\begin{array}{l}\mathrm{N}_{2} \\
\text { (ccstp/g } \\
\text { ) }\end{array}$ & Ar(ccstp/g \\
\hline SLP4 & T0 & 507 & 6.7 & 11. & 127 & 23.57 & 34.26 & 34.9 & 0,0183 & $4.06 * 10^{-4}$ \\
\hline SLP4 & $\begin{array}{l}\mathrm{T}+6 \mathrm{hrs} \\
(\mathrm{t} 1)\end{array}$ & 507 & $\begin{array}{l}6.7 \\
4\end{array}$ & 14 & 120 & 23.48 & 34.38 & 35.3 & 0.0179 & $3.98 * 10^{-4}$ \\
\hline $\begin{array}{l}(\mathrm{t} 1- \\
\mathrm{t} 0) / \mathrm{unc}\end{array}$ & & 0 & 0 & +5 & -1 & -1 & 0 & +1 & 0 & 0 \\
\hline $\begin{array}{l}\text { Captag } \\
\mathrm{e}\end{array}$ & T0 & 401 & $\begin{array}{l}5.8 \\
3\end{array}$ & $\begin{array}{l}12 . \\
5\end{array}$ & 183 & 61.18 & 49.55 & 20.3 & $\begin{array}{l}9.02 * 10^{-} \\
4\end{array}$ & $1.83 * 10^{-5}$ \\
\hline $\begin{array}{l}\text { Captag } \\
\text { e }\end{array}$ & $\mathrm{T}+3 \mathrm{hrs}$ & 401 & $\begin{array}{l}5.8 \\
9\end{array}$ & $\begin{array}{l}12 . \\
6\end{array}$ & 121 & & & & $\begin{array}{l}9.18 * 10^{-} \\
4\end{array}$ & $1.87 * 10^{-5}$ \\
\hline $\begin{array}{l}\text { Captag } \\
\mathrm{e}\end{array}$ & $\begin{array}{l}\mathrm{T}+6 \mathrm{hrs} \\
(\mathrm{t} 1)\end{array}$ & 401 & $\begin{array}{l}5.9 \\
6\end{array}$ & $\begin{array}{l}12 . \\
7\end{array}$ & 115 & 56.15 & 46.89 & 19.8 & $\begin{array}{l}9.26^{*} 10^{-} \\
4\end{array}$ & $1.88 * 10^{-5}$ \\
\hline $\begin{array}{l}\text { ( t1- } \\
\text { t0)/unc }\end{array}$ & & 0 & +1 & 0 & +7 & -10 & -5 & -1 & +0.5 & +0.5 \\
\hline Forage & T0 & 663 & $\begin{array}{l}6.3 \\
8\end{array}$ & $\begin{array}{l}12 . \\
5\end{array}$ & -4 & $<\mathrm{LQ}$ & 90.70 & 99.7 & 0.0256 & $4.29 * 10^{-4}$ \\
\hline
\end{tabular}




\begin{tabular}{|l|l|l|l|l|l|l|l|l|l|l|}
\hline Forage & $\mathrm{T}+3 \mathrm{hrs}$ & 660 & $\begin{array}{l}6.3 \\
3\end{array}$ & $\begin{array}{l}12 . \\
9\end{array}$ & 46 & & & & 0.0256 & $4.24 * 10^{-4}$ \\
\hline Forage & $\begin{array}{l}\mathrm{T}+6 \mathrm{hrs} \\
(\mathrm{t} 1)\end{array}$ & 661 & $\begin{array}{l}6.4 \\
5\end{array}$ & $\begin{array}{l}12 . \\
8\end{array}$ & 47 & 2.64 & 87.98 & 97.6 & 0.0177 & $4.36 * 10^{-4}$ \\
\hline $\begin{array}{l}\mathrm{t} 1- \\
\mathrm{t} 0) / \text { unc }\end{array}$ & & 0 & 1 & +1 & +5 & $\mathrm{nd}$ & -5 & -4 & -12 & 0 \\
\hline Unc. & --------- & $+/-10$ & $\begin{array}{l}1 /- \\
0.1\end{array}$ & $\begin{array}{l}0.5 \\
0 /-\end{array}$ & $+/-10$ & $+/-0.5$ & $+/-0.5$ & $+/-0.5$ & $+/-5 \%$ & $+/-5 \%$ \\
\hline
\end{tabular}

Table 2: Filed physic-chemical parameters measured on field, anions, nitrogen and argon results measured in the Rennes Laboratory.

Evolution of parameters is normalized to analytical uncertainty.

\begin{tabular}{|c|c|c|c|c|c|c|c|c|c|}
\hline $\begin{array}{l}\text { Borehol } \\
\text { e }\end{array}$ & $\begin{array}{l}\text { Samplin } \\
\text { g time }\end{array}$ & $\begin{array}{l}\text { CFC1 } \\
1 \\
\text { GR(A } \\
)\end{array}$ & $\begin{array}{l}\text { CFC11 } \\
\text { USGS(E }\end{array}$ & $\begin{array}{l}\text { CFC1 } \\
2 \\
\text { GR(A } \\
)\end{array}$ & $\begin{array}{l}\text { CFC12 } \\
\text { USGS(E }\end{array}$ & $\begin{array}{l}\text { CFC11 } \\
3 \\
\text { GR(A) }\end{array}$ & $\begin{array}{l}\text { CFC113 } \\
\text { USGS(E } \\
)\end{array}$ & $\mathrm{SF}_{6} \mathrm{GR}(\mathrm{A}$ & $\begin{array}{l}\mathrm{SF}_{6} \mathrm{USGS}(\mathrm{E} \\
)\end{array}$ \\
\hline SLP4 & to & $\begin{array}{l}0.988 \\
5\end{array}$ & 0.971 & $\begin{array}{l}0.469 \\
6\end{array}$ & 0.549 & 0.068 & 0.074 & $1.8 * 10^{-4}$ & $2.49+10^{-4}$ \\
\hline SLP4 & $\begin{array}{l}\text { t1 } \\
(+6 \mathrm{hrs})\end{array}$ & $\begin{array}{l}0.977 \\
6\end{array}$ & 0.806 & $\begin{array}{l}0.489 \\
3\end{array}$ & 0.474 & 0.041 & 0.057 & $1.7 * 10-4$ & $2.48^{*} 10^{-4}$ \\
\hline Unc & & 0.03 & 0.03 & 0.015 & 0.016 & 0.013 & 0.013 & $5 * 10^{-6}$ & $7 * 10^{-6}$ \\
\hline $\begin{array}{l}\text { (t1- } \\
\text { t0)/unc }\end{array}$ & & & -5 & +1 & -5 & -2 & -1 & -2 & 0 \\
\hline Captage & to & 3.869 & 3.782 & 2.417 & 2.491 & 0.366 & 0.337 & $2.26 * 10^{-3}$ & $2.45^{*} 10^{-3}$ \\
\hline Captage & $\mathrm{t}(+3 \mathrm{hrs})$ & 3.868 & 3.916 & 2.184 & 2.595 & 0.341 & 0.338 & & \\
\hline Captage & $\begin{array}{l}\mathrm{t} 1 \\
(+6 \mathrm{hrs})\end{array}$ & 3.901 & 3.923 & 2.232 & 2.491 & 0.265 & 0.334 & $2.15^{*} 10^{-3}$ & $2.96 * 10^{-3}$ \\
\hline Unc & & 0.1 & 0.1 & 0.07 & 0.07 & 0.01 & 0.01 & $7 * 10^{-5}$ & $7 * 10^{-5}$ \\
\hline $\begin{array}{l}\text { (t1- } \\
\text { t0)/unc }\end{array}$ & & 0 & +1 & -3 & 0 & -10 & 0 & -2 & +7 \\
\hline Forage & to & 0.034 & 0.014 & 0.963 & 1.102 & 0.032 & & $1.37 * 10^{-3}$ & $1.36 * 10^{-3}$ \\
\hline Forage & $\mathrm{t}(+3 \mathrm{hrs})$ & 0.030 & 0.048 & 0.951 & 1.063 & 0.039 & 0.011 & $1.32 * 10^{-3}$ & \\
\hline
\end{tabular}




\begin{tabular}{|l|l|l|l|l|l|l|l|l|l|}
\hline Forage & $\begin{array}{l}\mathrm{t} 1 \\
(+6 \mathrm{hrs})\end{array}$ & 0.053 & 0.056 & 1.086 & 1.079 & 0.055 & 0.025 & $1.39 * 10^{-3}$ & $1.34 * 10^{-3}$ \\
\hline Unc & & 0.01 & 0.01 & 0.03 & 0.03 & 0.01 & 0.01 & $4 * 10^{-5}$ & $4 * 10^{-5}$ \\
\hline $\begin{array}{l}\text { (t1- } \\
\text { t0)/unc }\end{array}$ & +2 & +4 & +4 & -1 & +2 & $+1^{*}$ & +1 & -1 \\
\hline
\end{tabular}

Table 3: dissolved gases concentrations ( $\mathrm{pmol} / \mathrm{kg}$ ) measured at regular intervals by

Geosciences Rennes and USGS Reston laboratory during sampling operations. Evolution of parameters is normalized to analytical uncertainty. *: evolution through three last hours.
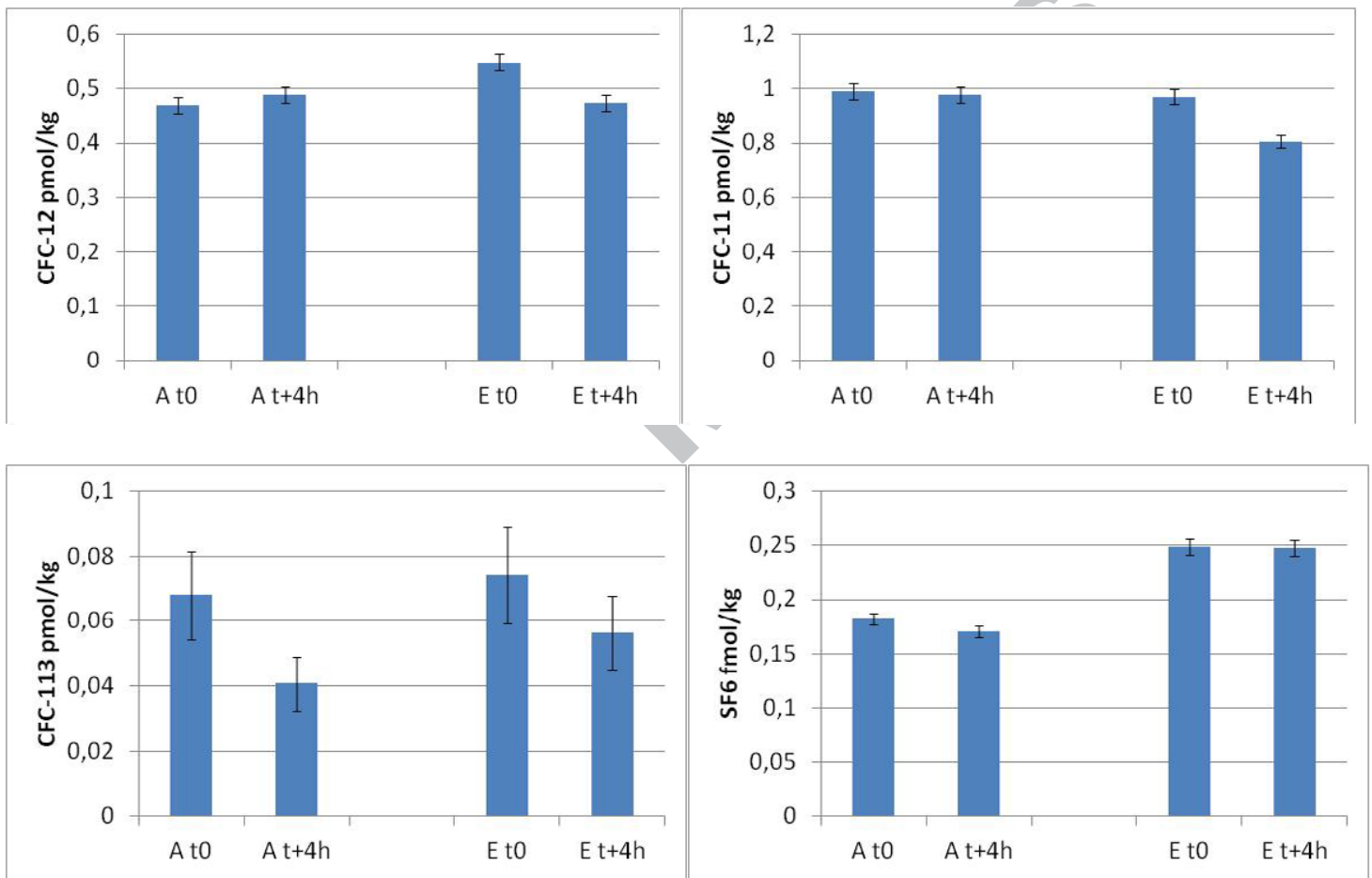

Figure 1: Eyolution of CFCs and SF6 concentrations in groundwater from SLP4 well, at the beginning ( $(0)$ and the end $(\mathrm{t}+4 \mathrm{~h})$ of pumping. Data obtained by GR (A) and USGS (E) laboratories. 

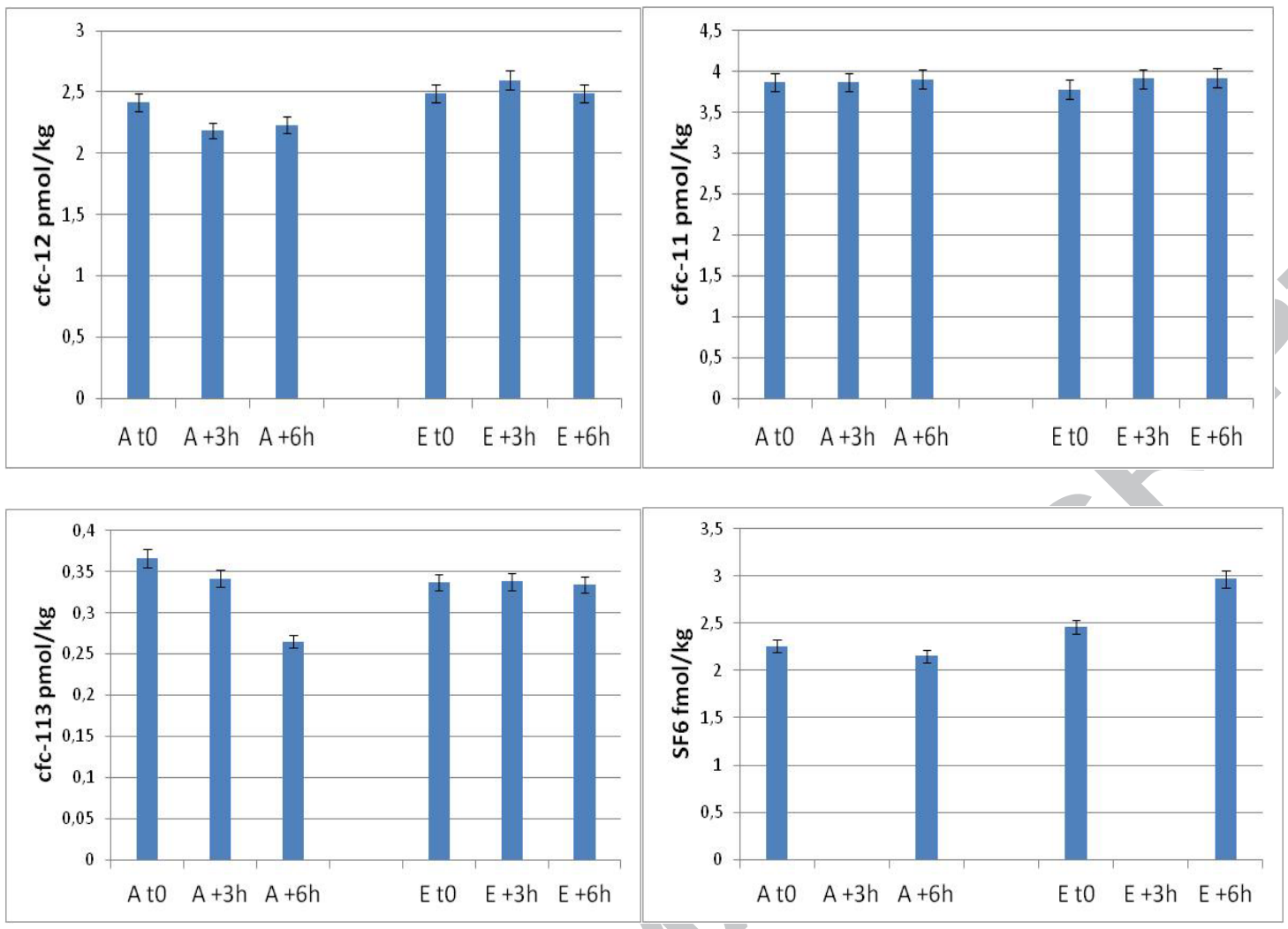

Figure 2: Evolution of $\mathrm{CFCs}$ and $\mathrm{SF}_{6}$ concentrations in groundwater from "Captage" well during sampling. Data obtained by GR (A) and USGS (E) laboratories.
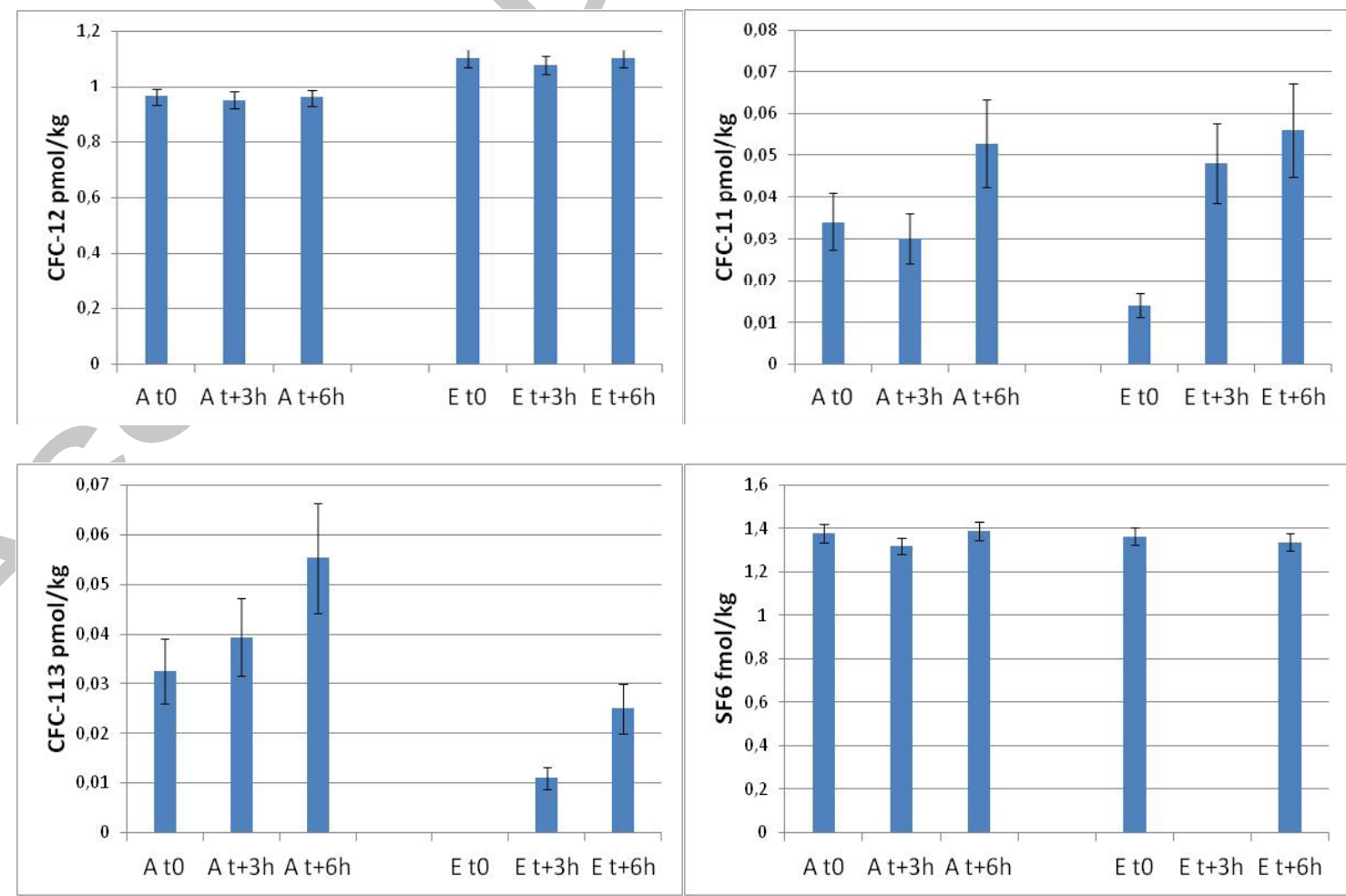
Figure 3 : Evolution of CFCs and SF6 concentrations in groundwater from "Forage" well during pumping. Data obtained by GR (A) and USGS (E).

\section{Highlights}

- We present two intercomparison exercices dedicated to groundwater dating

- 31 labs from 14 countries have participated to the exercises

- Field parameters, anions and dissolved gases were measured all along the sampling

- Supply boreholes can be used for intercomparison exercises on environmental tracers 